\title{
ANALISIS PENERAPAN AKUNTANSI PAJAK TANGGUHAN PADA LAPORAN KEUANGAN PT BUMI SARANA UTAMA
}

\author{
Dahniyar Daud *) \\ niardaudismail@gmail.com
}

\begin{abstract}
ABSTRAK
Tujuan penelitian ini adalah untuk mengetahui dan menganalisa penerapan akuntansi pajak tangguhan pada laporan keuangan yang dilakukan oleh PT Bumi Sarana Utama. Metode penelitian yang digunakan adalah descriptive comparative. Penelitian berupa studi kasus pada PT Bumi Sarana Utama. Data yang digunakan merupakan data sekunder, yaitu laporan keuangan perusahaan tahun 2009 dan 2010. Hasil penelitian menunjukkan bahwa perusahaan telah menerapkan akuntansi pajak penghasilan pada laporan keuangan tahun 2009, sesuai dengan PSAK No. 46, berdasarkan perhitungan tersebut maka didapatkan saldo kewajiban pajak tangguhan Rp. 32.759.520. pada tahun 2010, penerapan akuntansi pajak tangguhan yang dilakukan oleh perusahaan tidak sesuai dengan PSAK No. 46. Oleh karena itu harus dilakukan suatu jurnal penyesuaian untuk akun pajak tangguhan.
\end{abstract}

\section{Pendahuluan}

Akuntansi pajak tangguhan diatur dalam Pernyataan Standar Akuntansi Keuangan Nomor 46. Secara umum, PSAK No. 46 diterbitkan untuk memperbaiki kualitas laporan keuangan yang berkaitan dengan pajak penghasilan. PSAK No. 46 merupakan standar akuntansi yang mengatur perlakuan akuntansi untuk pajak. Kerena merupakan standar, maka PSAK No. 46 wajib diterapkan dalam laporan keuangan perusahaan yang telah listing, dan dianjurkan untuk digunakan bagi perusahaan yang belum listing. PSAK No. 46 juga mengatur tentang akuntansi pajak penghasilan menggunakan dasar akrual, yang secara komprehensif merupakan pendekatan aktiva kewajiban (asset-liability approach) atau berorientasi pada neraca (balance sheet oriented).

Ketentuan dalam UU PPh dan PSAK terkait pengakuan pendapatan dan beban tidak sama, karena memiliki tujuan yang berbeda. Perbedaan antara pajak dan akuntansi dapat dibedakan menjadi dua yaitu perbedaan permanen dan perbedaan temporer, sehingga setiap akhir pelaporan entitas melakukan rekonsiliasi fiskal atau koreksi fiskal atas laba sebelum pajak untuk menghitung jumlah penghasilan kena pajak. Oleh karena itu, penerapan PSAK No. 46 tentang Akuntansi Pajak Penghasilan diharapakan dapat menjembatani antara peraturan perpajakan dengan ketentuan akuntansi. PSAK No.46 mengatur pengakuan, pengukuran, penyajian, dan pengungkapan pajak penghasilan entitas.

PSAK No. 46 entitas tidak hanya diwajibkan memenuhi ketentuan perpajakan untuk membayar dan melaporkan pajak, namun juga menyajikan dan mengungkapkan informasi tersebut dalam laporan keuangan. Hal ini membantu para pengguna laporan keuangan tidak salah dalam membaca laporan keuangan. Suatu perusahaan bisa saja membayar pajak lebih kecil saat ini, tapi sebenarnya 
memiliki potensi hutang pajak yang lebih besar di masa datang. Atau sebaliknya, bisa saja perusahaan membayar pajak lebih besar saat ini, tetapi sebenarnya memiliki potensi hutang pajak yang lebih kecil di masa datang. Hal inilah yang disebut dengan pajak tangguhan.

PT Bumi Sarana Utama adalah perusahaan yang tidak dikecualikan dalam penerapan PSAK secara keseluruhan. PSAK No. 46 mengenai pajak tangguhan juga wajib diterapkan perusahaan ini agar dapat dinilai wajar dalam pelaporan keuangannya. Berdasarkan data laporan keuangan audited perusahaan, diketahui bahwa perusahaan ini telah efektif menerapkan Standar Akuntansi Pajak Tangguhan sejak 2007. Berdasarkan uraian tersebut, maka penelitian ini akan mengambil topik :"Analisis Penerapan Akuntansi Pajak Tangguhan pada Laporan Keuangan PT Bumi Sarana Utama”.

\section{Rumusan Masalah.}

Berdasarkan latar belakang di atas, maka rumusan masalah yang disajikan dalam penelitian ini adalah :

1) Bagaimana penerapan akuntansi pajak tangguhan pada laporan keuangan PT Bumi Sarana Utama?

2) Apakah penerapan akuntansi pajak tangguhan pada laporan keuangan PT Bumi Sarana Utama sudah sesuai dengan PSAK 46 ?

\section{Tujuan Penelitian}

Adapun tujuan penelitian ini adalah untuk mengetahui dan menganalisa penerapan akuntansi pajak tangguhan pada laporan keuangan yang dilakukan oleh PT Bumi Sarana Utama sesuai dengan standar yang berlaku.

\section{Tinjauan Pustaka}

\section{Akuntansi Komersil dan Akuntansi Fiskal}

Akuntansi komersial merupakan kegiatan jasa yang berfungsi menyajikan informasi kuantitatif mengenai suatu entitas ekonomi sebagai dasar untuk pengambilan suatu keputusan ekonomis terhadap beberapa alterntif yang tersedia, sedangkan akuntansi fiskal adalah bidang akuntansi yang berkaitan dengan perhitungan perpajakan, yang mengacu pada peraturan, undang-undang, dan aturan pelaksanaan perpajakan.

Pengertian pembukuan dalam undang-undang perpajakan sedikit berbeda dengan pengertian pembukuan menurut akuntansi. Menurut Gunadi (2001:9), "pembukuan (book keeping) adalah pencatatan data perusahaan dengan teknik tertentu dan mengolahnya sehingga dapat disusun menjadi laporan keuangan". Sedangkan pasal 1 (29) KUP: "Pembukuan adalah proses pencatatan yang dilakukan secara teratur untuk mengumpulkan data dan informasi keuangan yang meliputi harta, kewajiban, modal, penghasilan dan biaya, serta jumlah harga perolehan dan penyerahan barang atau jasa, yang ditutup dengan menyusun laporan keuangan berupa neraca dan laporan laba-rugi untuk periode Tahun Pajak tersebut". 
Menurut Pardiat (2007:1), tujuan penyelenggaraan pembukuan adalah untuk menghitung penghasilan neto fiskal berdasarkan UU-Perpajakan dan peraturan pelaksanaannya, yaitu:

a) Peraturan Pemerintah (PP)

b) Keputusan Presidan (KEPRES)

c) Keputusan atau Peraturan Menteri Keuangan

d) Keputusan Direktur Jenderal Pajak, atau Peraturan Direktur Jenderal Pajak.

e) Surat Edaran Direktur Jenderal Pajak.

f) Keputusan Keberatan dari Direktur Jenderal Pajak dan Putusan Banding dari

Pengadilan Pajak, hanya untuk WP yang bersangkutan.

Perbedaan laporan keuangan komersial dengan laporan keuangan fiskal, sama halnya dengan membicarakan masalah akuntansi fiskal, karena akuntansi fiskal umumnya menyangkut masalah kapan suatu penghasilan diakui sebagai pengurangan dari penghasilan tersebut. Masalah ini sesungguhnya tergantung kepada tahun pajak atau tahun buku tahun wajib pajak (pembayar pajak), metode akuntansi yang digunakannya serta konsep yang menjadi pedomannya.

Perbedaan utama antara laporan keuangan komersial dengan laporan keuangan fiskal disebabkan karenaperbedaan tujuan serta dasar hukumnya, walaupun dalam beberapa hal terdapat kesamaan antara akuntansi fiskal yang mengacu kepada standard akuntansi keuangan. Menurut Waluyo (2000:45), perbedaan antara akuntansi komersial dengan akuntansi fiskal antara lain:

a. Dasar penyusunan

Dasar penyusunan laporan keuangan komersial adalah standard akuntansi keuangan, sedangkan dasar penyusunan laporan keuangan fiskal adalah standar akuntansi keuangan yang disesuaikan dengan Undang-undang perpajakan yang berlaku.

b. Konsep

Konsep laporan keuangan komersial terdiri dari:

1. Dasar akrual (accrual basis)

Pengaruh transaksi dan peristiwa lain diakui pada saat kejadian dan bukan pada saat kas atau setara kas diterima atau dibayar atau dicatat dalam catatan akuntansi serta dilaporkan dalam laporan keuangan pada periode bersangkutan.

2. Mempertemukan beban dengan pendapatan yang paling tepat (proper matching cost and revenue) melibatkan pengakuan penghasilan dan beban atau bersamaan yang dihasilkan secara langsung dan bersama-sama dari transaksi atau peristiwa lain yang sama.

3. Konservatif (conservative)

Konservatif yaitu konsep hati-hati, mungkin rugi yang di taksir sudah diakui sebagai kerugian, dengan membentuk penyisihan (cadangan) pada akhir tahun atau dengan membuat adjustment, contoh: penyisihan kerugian piutang, penyisihan potongan penjualan, penyisihan retur penjualan, penyisihan klaim, penyisihan setelah biaya penjualan, penyisihan penurunan nilai surat-surat berharga, penilaian persediaan dengan metode 
harga pokok dan harga pasar mana yang lebih rendah, kerugian piutang (metode langsung dan metode penyisihan).

4. Materialitas digunakan oleh auditor untuk menyatakan wajar/tidak wajar dalam penilaian laporan keuangan komersial.

Konsep laporan keuangan fiskal terdiri dari:

1. Akrual Stelsel (stelsel accrual)

Pengaruh transaksi mengakui penghasilan pada saat diperoleh penghasilan, walaupun penghasilan tersebut belum diterima tunai, dan mengurangkannya dengan biaya-biaya pada saat biaya tersebut terutang, walaupun biaya tersebut belum dibayar tunai. Sebagai contoh misalnya: pengeluaran untuk suatu pembayaran dimuka.

2. Mempertemukan antara biaya untuk mendapat, menagih, dan memelihara penghasilan yang merupakan objek pajak penghasilan (proper matching taxable income and deductible expense) sesuai dengan prinsip $3 \mathrm{M}$ (mendapatkan, menagih, dan memelihara) penghasilan, beban (expense) yang dapat dikurangkan atas penghasilan kena pajak (taxable income) adalah beban yang timbul dalam hubungannya dengan penghasilan (match and link). Dalam suatu transaksi akan melibatkan lebih dari satu pihak lainnya akan membukukan sebagai beban.

3. Konservatif tidak digunakan.

4. Materialistis digunakan oleh auditor untuk menyatakan wajar/tidak wajar dalam penilaian laporan keuangan komersial tidak digunakan (selain bank dan sewa guna usaha dengan hak opsi, hanya diperkenankan dengan metode langsung).

c. Tujuan

Tujuan laporan keuangan komersial adalah menghitung laba bersih, mengukur kinerja, mengukur keadaan posisi keuangan, mengukur keadaan kekayaan danlaporannya ditujukan untuk pihak ketiga dan manajemen. Sedangkan tujuan laporan keuangan fiskal adalah menghitung besarnya pajak yang terutang dan laporannya ditujukan kepada pihak fiskus.

d. Akibat penyimpangan

Akibat penyimpangan dari laporan keuangan komersial, misalnya: pengambilan keputusan yang tidak tepat oleh manajemen, adanya opini yang buruk terhadap laporan keuangan yang berhubungan langsung dengan kreditor, investor, dan pemilik perusahaan. Sedangkan akibat penyimpangan dari laporan keuangan fiskal adalah dikenakannya sanksi di bidang perpajakan antara lain: sanksi administrasi yang berupa denda, bunga atau kenaikan sedangkan sanksi pidananya berupa kurungan atau penjara.

Menurut Gunadi (2001: 201-202), Perbedaan Laporan keuangan Komersial dengan Laporan keuangan Fiskal disebabkan antara lain:

1. Perbedaan apa yang dianggap penghasilan menurut ketentuan perpajakan dan praktek akuntansi. 
2. Ketidaksamaan pendekatan perhitungan penghasilan, misalnya link and match, antara beban dan penghasilan, metode depresiasi, penerapan norma perhitungan, pemajakan dengan metode basis bruto atau netto.

3. Pemberian relif atau keringanan yang lainnya, misalnya laba rugi pelaporan aktiva atau penghasilan hibah, penghasilan tidak kena pajak, perangsang penanaman, dan penyusutan dipercepat.

4. Perbedaan perlakuan kerugian misalnya kerugian mancanegara atau harta yang tidak dipakai dalam usaha.

Bila ditinjau kembali maka sebenarnya perbedaan laporan keuangan kemersial dengan laporan keuangan fiskal terdapat pada:

1. Perbedaan mengenai konsep penghasilan atau pendapatan

Konsep penghasilan (income) menurut IAI (2011:13), adalah "Kenaikan manfaat ekonomi selama suatu periode akuntansi dalam bentuk pemasukan atau penambahan aset atau penurunan kewajiban yang mengakibatkan kenaikan ekuitas yang tidak berasal dari kontribusi penanaman modal". Dari sisi fiskal, konsep penghasilan tidak jauh berbedadengan konsep akuntansi, yaitu: Segala tambahan kemampuan ekonomis yang diterima/diperoleh Wajib Pajak baik yang berasal dari Indonesia maupun dari luar Indonesia yang bisa dikonsumsi atau menambah kekayaan Wajib Pajak dengan nama dan dalam bentuk apapun. Lebih lanjut fiskal membedakan penghasilan tersebut menjadi tiga kelompok yang sesuai dengan UU Pajak Penghasilan Tahun 2008, yaitu:

a. Penghasilan yang merupakan Objek Pajak Penghasilan

b. Penghasilan yang dikenakan Pajak Penghasilan Final

c. Penghasilan yang bukan merupakan Objek Pajak Penghasilan

2. Perbedaan Konsep Beban (Biaya)

Beban (expense) menurut IAI (2011:13), diartikan sebagai "Penurunan manfaat ekonomi selama suatu periode akuntansi dalam bentuk arus keluar atau berkurangnya aktiva atau terjadinya kewajiban yang mengakibatkan penurunan ekuitas yang tidak menyangkut pembagian kepada penanam modal".

Sisi Fiskal sendiri, mengartikan Beban sebagai biaya untuk menagih, memperoleh, dan memelihara penghasilan atau biaya yang berhubungan langsung dengan perolehan penghasilan. Perbedaan inilah yang menyebabkan pihak fiskus sering berbeda pendapat dengan wajib pajak dalam hal menentukan beban/biaya yang boleh atau tidak boleh dikurangkan sehingga harus dikeluarkan/tidak boleh diperhitungkan sebagai pengurangan penghasilan.

3. Perbedaan dalam konsep Penyusutan dan Nilai Persediaan

Perbedaan dalam konsep antara akuntansi dengan peraturan perpajakan terutama menyangkut konsep penyusutan penilaian persediaan barang dagangan.

a. Konsep Penyusutan

Perbedaan utama antara akuntansi dengan undang-undang perpajakan adalah penentuan umur aktiva dan metode penyusutan yang boleh digunakan. Akuntansi menentukan umur aktiva berdasarkan umur 
sebenarnya walaupun penentuan umur tersebut tidak terlepas dari tafsiran judgement.Menurut IAI (2011:13), Akuntansi memiliki beberapa metode penyusutan yaitu:

1. Metode Garis Lurus (straight line method), yaitu menghasilkan pembebanan yang tetap selama umur manfaat asset jika dinilai residunya tidak berubah.

2. Metode Saldo Menurun (diminishing balance method), yaitu menghasilkan pembebanan yang menurun selama umur manfaat aset.

3. Metode Jumlah Unit (sum of the unit method), yaitu menghasilkan pembebanan yang menurun selama umur manfaat aset.

b. Konsep Nilai Persediaan

Dalam undang-undang pajak penghasilan Indonesia, persediaan dan pemakaian persediaan untuk menghitung harga pokok dinilai berdasarkan harga perolehan (cost) yang dilakukan dengan metode ratarata (average) atau dengan metode mendahulukan persediaan yang diperoleh pertama yang dikenal dengan first in first out (FIFO). Penggunaan metode tersebut harus dilakukan secara konsisten.

\section{Koreksi Fiskal}

Koreksi fiskal adalah koreksi atau penyesuaian yang harus dilakukan oleh wajib pajak sebelum menghitung Pajak Penghasilan ( $\mathrm{PPh}$ ) bagi wajib pajak badan dan wajib pajak orang pribadi (yang menggunakan pembukuan dalam menghitung penghasilan kena pajak). Koreksi fiskal terjadi karena adanya perbedaan perlakuan/pengakuan penghasilan maupun biaya antara akuntansi komersial dengan akuntansi pajak. Koreksi fiskal meliputi pengakuan pendapatan dan biaya yang dapat berupa koreksi positif dan koreksi negatif.

a. Koreksi Fiskal Positif

Koreksi fiskal positif adalah koreksi/penyesuaian yang akan mengakibatkan meningkatnya laba kena pajak yang pada akhirnya akan membuat PPh Badan Terhutangnya juga akan meningkat.

b. Koreksi fiskal Negatif

Koreksi fiskal negatif adalah koreksi/penyesuaian yang akan mengakibatkan menurunnya laba kena pajak yang membuat PPh badan terhutangnya juga akan menurun.

Terdapat perbedaan dalam perlakuan penetapan pendapatan dan biaya menurut Undang-Undang Perpajakan Nomor 17 Tahun 2000 dengan Standar Akuntansi Keuangan sebagai akibat dari adanya beda tetap dan beda sementara. Perlakuan akuntansi terhadap perbedaan tersebut perlu dilakukan rekonsiliasi antara laporan keuangan komersial dengan laporan keuangan fiskal, dan pengaruh perbedaan tersebut terhadap laporan keuangan yaitu pada besarnya jumlah pajak terutang dari jumlah laba usaha.

\section{Pajak Penghasilan}

Pajak penghasilan adalah pajak yang dibebankan pada penghasilan perorangan, perusahaan atau badan hokum lainnya. Pajak penghasilan bisa diberlakukan progresif, proporsional, atau regresif. Pengenaan pajak langsung sebagai cikal bakal dari pajak penghasilan sudah terdapat pada zaman Romawi 
Kuno, antara lain dengan adanya pungutan yang bernama tributum yang berlaku sampai dengan tahun 167 sebelum masehi.

Undang-Undang Nomor 7 tahun 1983 tentang Pajak Penghasilan (PPh) yang telah diubah dengan Undang-Undang Nomor 7 tahun 1991. Undang-Undang Nomor 10 tahun 1994, Undang-Undang Nomor 17 tahun 2000 dan terakhir diubah dengan Undang-Undang Nomor 36 tahun 2008 mengatur mengenai pajak atas penghasilan yang diterima atau diperoleh orang pribadi dan badan. Diana, Anastasia (2009:163), menjelaskan bahwa pajak penghasilan dikenakan terhadap Subjek Pajak berkenaan dengan penghasilan yang diterima atau diperolehnya dalam tahun pajak. Subjek Pajak yang menerima atau memperoleh penghasilan tersebut disebut sebagai Wajib Pajak (WP).

\section{Akuntansi Pajak Penghasilan}

Tahun 1998 Ikatan Akuntan Indonesia (IAI) menerbitkan Pernyataan Standar akuntansi Keuangan No. 46 (PSAK 46) mengenai akuntansi pajak penghasilan. PSAK 46 mengatur perlakuan akuntansi untuk pajak penghasilan. Masalah yang timbul adalah bagaimana pengakuan pengaruh pajak pada periode berjalan dan periode mendatang terhadap transaksi yang telah diakui dalam laporan keuangan dan Surat Pemberitahuan (SPT) serta kompensasi kerugian fiskal yang belum digunakan. Penerapan PSAK 46 ini diharapkan dapat menjembatani antara peraturan perpajakan dengan ketentuan akuntansi. Menurut Jusuf Halim (2001) tujuan penerapan PSAK 46 ini adalah untuk mengarur (a) pengakuan terhadap future tax effect yang timbul sebagai akibat adanya transaksi dan peristiwa yang telah diakui dalam laporan keuangan dan SPT, (b) pengakuan terhadap future tax effect dari kompensasi kerugian fiskal yang belum digunakan, dan (c) penyajian pajak penghasilan dalam laporan keuangan dan pengungkapan informasi yang relevan. (Estralita Trisnawati, 2004:182).

\section{Hipotesis}

Berdasarkan uraian-uraian diatas, maka penulis dapat merumuskan hipotesis penelitian sebagai berikut: Diduga bahwa, penerapan akuntansi pajak tangguhan pada laporan keuangan yang dilakukan oleh PT Bumi Sarana Utama sesuai dengan standar yang berlaku.

\section{Metode Penelitian}

\section{Lokasi dan Waktu Penelitian}

Lokasi penelitian yang dilaksanakan di Penelitian akan dilakukan pada PT. Bumi sarana Utama yang terletak di Jalan Sam Ratulangi, Wisma Kalla, Makassar. Waktu penelitian yang digunakan adalah 2 bulan lamanya.

\section{Jenis dan Sumber Data}

Jenis data yang digunakan dalam penelitian ini adalah:

1. Data Kualitatif yaitu semua data yang sifatnya informasi atau keterangan berupa penjelasan-penjelasan mengenai koreksi fiskal yang dilakukan perusahaan dalam menyusun laporan keuangan fiskal. 
2. Data Kuantitatif yaitu semua data yang sifatnya angka-angka atau dapat dihitung, yang berkaitan dengan laporan keuangan perusahaan dan koreksi fiskal.

Sedangkan data yang dikumpulkan dikelompokkan berdasarkan sumber data, yaitu:

1. Data Primer yaitu semua data (berupa keterangan dan angka-angka) yang diperoleh melalui observasi dan wawancara.

2. Data Sekunder yaitu semua data yang diperoleh melalui data-data keuangan yang berhubungan dengan penelitian.

\section{Metode Pengumpulan Data}

Adapun metode pengumpulan data yang digunakan dalam penelitian ini adalah :

1. Penelitian kepustakaan, yaitu metode pengumpulan data dengan cara melakukan peninjauan pustaka dari berbagai literature, karya ilmiah, majalah, dan buku-buku yang menyangkut teori-teori yang relevan dengan masalah yang akan dibahas.

2. Penelitian lapangan, yaitu metode pengumpulan data yang dilakukan dilokasi (objek penelitian) secara langsung, dan Mengakses Website dan Situs-situs terkait yang menyediakan informasi yang berkaitan dengan masalah tersebut.

Adapun penelitian lapangan dilakukan dengan cara sebagai berikut :

1. Observasi, yaitu dengan melakukan pengamatan langsung ke perusahaan.

2. Wawancara, yaitu melakukan wawancara langsung dengan pihak-pihak yang berkompeten di perusahaan.

\section{Metode Analisis}

Metode analisis yang digunakan dalam penelitian ini adalah menggunakan analisis deskriptif comparative, yaitu menjelaskan secara detail tentang perlakuan akuntansi yang berpengaruh dalam penyajian pajak tangguhan dan membandingkan laporan keuangan sebelum dan sesudah penerapan PSAK No. 46 khususnya mengenai pajak tangguhan pada PT. Bumi Sarana Utama.

Data yang diperoleh dari perusahaan akan dianalisis sesuai dengan tujuan penelitian, yaitu :

a. Menganalisis laporan keuangan komersial yang telah dikoreksi fiskal untuk diketahui besarnya pajak penghasilan.

b. Menganalisis akun-akun neraca yang menunjukkan perbedaan pengakuan penghasilan dan/atau beban menurut peraturan perpajakan dengan perusahaan.

c. Menganalisis penyebab timbulnya aktiva dan/ atau kewajiban pajak tangguhan.

d. Membandiingkan pengakuan aktiva dan/atau kewajiban pajak tangguhan yang dilakukan perusahaan dengan PSAK No. 46.

\section{Hasil dan Pembahasan}

Untuk menerapkan PSAK No. 46, perusahaan seharusnya mengakui seluruh konsekuensi pajak pada periode berjalan dan periode mendatang. Tanggung jawab pengakuan konsekuensi pajak dapat dilakukan dengan menghitung dan mengakui adanya pajak tangguhan (deferred tax) atas "future tax 
effects" dengan menggunakan "balance sheet liability method" atau "asset/liability method".

PT Bumi Sarana Utama telah menerapkan standar akuntansi mengenai akuntansi pajak penghasilan. Prosedur yang dilakukan oleh perusahaan ini dalam mengakui konsekuensi perhitungan pajak adalah sebagai berikut:

a. Melakukan rekonsiliasi fiskal terhadap laporan keuangan komersial sesuai dengan peraturan perpajakan. Hal ini dilakukan dengan mempertimbangkan perbedaan peraturan perpajakan dengan Standar Akuntansi Keuangan terhadap pengakuan pendapatan maupun beban.

b. Menghitung beban pajak kini sesuai dengan hasil laba fiskal yang didapatkan dari rekonsiliasi fiskal lalu dikalikan dengan persentasi pajak sesuai dengan peraturan perpajakan.

c. Menghitung utang pajak, pajak yang masih harus dibayar. Jumlah ini didapatkan dengan memperhitungkan pajak yang dibayar di muka dan saldo utang pajak tahun sebelumnya.

d. Menghitung pajak tangguhan dengan mempertimbangkan beda sementara(waktu) antara peraturan perpajakan dengan Standar Akuntansi yang berlaku.

e. Menetapkan jumlah pajak tangguhan sebagai aktiva (kewajiban) pajak tangguhan dengan memperhitungkan jumlah aktiva (kewajiban) pajak tangguhan awal.

Berdasarkan prosedur yang dijabarkan di atas, dapat diketahui bahwa PT. Bumi Sarana Utama telah mengakui semua konsekuensi atas pajak di masa kini dan masa yang akan datang. Hal ini berarti bahwa jika prosedur ini dijalankan dengan benar, maka PT Bumi Sarana Utama telah menerapkan sepenuhnya PSAK No. 46 pada laporan keuangannya.

\section{Penerapan PSAK No. 46 pada Laporan Keuangan PT Bumi Sarana Utama Penerapan PSAK No. 46 pada Laporan Keuangan tahun 2009}

Berdasarkan tahapan prosedur yang dijabarkan sebelumnya, hal pertama yang harus dilakukan adalah rekonsiliasi fiskal. Berikut ini disajikan prosedur penerapan pajak tangguhan PT. Bumi Sarana Utama yang disusun sesuai dengan Pernyataan Standar Akuntansi Keuangan No. 46:

a. Kompensasi rugi anak perusahaan, anak perusahaan yang mengalami rugi dikompensasikan ke laba perusahaan induk. Nilai ini mengurangi jumlah laba komersil.

b. Representasi dan jamuan, berdaasarkan Pasal 9 Ayat (1) UU Pajak Penghasilan, biaya jamuan tanpa daftar nominative dikategorikan sebagai non deductible expense (biaya yang tidak dapat dikurangkan). Oleh karena itu, biaya ini dikoreksi sebagai koreksi positif, menambah laba komersil sebesar Rp. 724.133.355.

c. Pendapatan bunga dan jasa giro, berdasarkan UU Pajak Penghasilan Tahun 2008, pendapatan bunga bukan merupakan objek pajak. Oleh karena itu, nilai pendapatan ini dikurangkan dari laba komersial sebesar Rp. 403.654.064.

d. Biaya yang tidak termasuk dalam biaya untuk mendapatkan, menagih dan memelihara penghasilan. Hal ini jelas tidak termaasuk biaya yang dapat 
dikurangkan. Yang termasuk dalam kelompok biaya ini adalah biaya untuk kepentingan pribadi direksi.

e. Untuk perbedaan penyusutan aset pembiayaan, hal ini termasuk beda temporer. Perbedaaan ini terjadi akibat pengakuan penyusutan yang dilakukan oleh perusahaan yang tidak diakui oleh pajak, meskipun di masa yang akan datang, apabila terjadi pemindahan kepemilikan, pajak akan mengakuinya. Oleh karena itu, perbedaan ini termasuk perbedaan temporer.

f. Penyisihan piutang tidak diakui oleh pajak hingga dinyatakan bahwa piutang itu benar-benar tidak tertagih. Oleh karena itu, perbedaan akibat penyisihan piutang ini dikategorikan sebagai perbedaan waktu.

g. Setelah laba fiskal didapatkan, kemudian dikalikan dengan persentasi pajak yaitu 28\%, maka taksiran pajak kini adalah Rp. 6.651.835.748

Prosedur berikutnya adalah menghitung hutang pajak dan pajak yang masih harus dibayar. Yaitu sebagai berikut:

\begin{tabular}{|l|r|}
\hline Keterangan & \multicolumn{1}{|l|}{ Jumlah } \\
\hline Taksiran pajak kini & 6.651 .835 .748 \\
Dikurangi & \\
Pajak dibayar dimuka : & 2.479 .475 .340 \\
PPh pasal 25 & 425.361 .623 \\
PPh pasal 22 & 3.746 .998 .785 \\
Jumlah & \\
Saldo hutang pajak tahun sebelumnya & \\
Hutang Pajak Pasal 29 & 3.746 .998 .785 \\
PPh pasal 21 & 146.672 .179 \\
PPh pasal 23 & 51.878 .533 \\
PPh pasal 25 & 7.076 .390 .433 \\
PPh pasal 29 & 3.746 .998 .785 \\
PPN & 1.467 .760 .467 \\
Jumlah Pajak Yang Masih Harus Dibayar & 12.489 .700 .397 \\
& \\
\hline
\end{tabular}


Langkah selanjutnya yaitu menghitung pajak tangguhan dengan mempertimbangkan beda sementara dari laba komersil dengan laba fiskal. Sesuai dengan Pernyataan Standar Akuntansi Keuangan No 46 mengenai pajak tangguhan, beban pajak tangguhan didapatkan dengan mengalikan persentasi pajak dengan beda waktu. Oleh karena itu, beban pajak tangguhan didapatkan: Aktiva (kewajiban) pajak tangguhan tahun 2009 = beda sementara tahun $2009 \mathrm{x}$ persentasi tariff pajak badan.

Diketahui: beda sementara tahun $2009=663.135 .721$

Persentasi tariff pajak $=28 \%$

Jadi, beban pajak tangguhan tahun $2009=663.135 .721 \times 28 \%=185.678 .002$

\section{BEDA WAKTU}

Penyusutan aset sewa pembiayaan

$(663.135 .721)$

Penyisihan Piutang

estimasi manfaat karyawan

Jumlah beda waktu

$(663.135 .721)$

persentasi pajak

$28 \%$

BEBAN PAJAK TANGGUHAN

(185.678.002)

Saldo awal Aktiva (kewajiban) pajak tangguhan 152.918.482

Jumlah Kewajiban Pajak tangguhan

32.759 .520

\section{Penerapan PSAK No. 46 pada Laporan Keuangan tahun 2010}

Berdasarkan tahapan prosedur yang dijabarkan sebelumnya, hal pertama yang harus dilakukan adalah rekonsiliasi fiskal. Berikut ini disajikan prosedur penerapan pajak tangguhan PT. Bumi Sarana Utama yang disusun sesuai dengan Pernyataan Standar Akuntansi Keuangan No. 46:

a. Kompensasi rugi anak perusahaan, anak perusahaan yang mengalami rugi dikompensasikan ke laba perusahaan induk. Nilai ini mengurangi jumlah laba komersil.

b. Representasi dan jamuan, berdaasarkan Pasal 9 Ayat (1) UU Pajak Penghasilan, biaya jamuan tanpa daftar nominative dikategorikan sebagai non deductible expense (biaya yang tidak dapat dikurangkan). Oleh karena itu, biaya ini dikoreksi sebagai koreksi positif, menambah laba komersil sebesar Rp. 752.071.100.

c. Pendapatan bunga dan jasa giro, berdasarkan UU Pajak Penghasilan Tahun 2008, pendapatan bunga bukan merupakan objek pajak. Oleh karena itu, nilai pendapatan ini dikurangkan dari laba komersial sebesar Rp. 531.092.755

d. Biaya yang tidak termasuk dalam biaya untuk mendapatkan, menagih dan memelihara penghasilan. Hal ini jelas tidak termaasuk biaya yang dapat dikurangkan. Yang termasuk dalam kelompok biaya ini adalah biaya untuk kepentingan pribadi direksi.

e. Untuk perbedaan penyusutan aset pembiayaan, hal ini termasuk beda temporer. Perbedaaan ini terjadi akibat pengakuan penyusutan yang dilakukan oleh perusahaan yang tidak diakui oleh pajak, meskipun di masa yang akan datang, apabila terjadi pemindahan kepemilikan, pajak akan mengakuinya. Oleh karena itu, perbedaan ini termasuk perbedaan temporer. 
f. Penyisihan piutang tidak diakui oleh pajak hingga dinyatakan bahwa piutang itu benar-benar tidak tertagih. Oleh karena itu, perbedaan akibat penyisihan piutang ini dikategorikan sebagai perbedaan waktu.

g. Setelah laba fiskal didapatkan, kemudian dikalikan dengan persentasi pajak yaitu 28\%, maka taksiran pajak kini adalah Rp. 9.655.837.328

Prosedur berikutnya adalah menghitung hutang pajak dan pajak yang masih harus dibayar. Yaitu sebagai berikut:

\begin{tabular}{|l|r|}
\hline Keterangan & \multicolumn{1}{|l|}{ Jumlah } \\
\hline Taksiran pajak kini & $\mathbf{9 . 6 5 5 . 8 3 7 . 3 2 8}$ \\
Dikurangi & \\
Pajak dibayar dimuka : & 3.951 .539 .264 \\
PPh pasal 25 & 2.545 .676 .946 \\
PPh pasal 22 & 3.158 .621 .119 \\
Jumlah & 1.983 .677 .345 \\
Saldo hutang pajak tahun sebelumnya & 5.142 .298 .464 \\
Hutang Pajak Pasal 29 & 215.284 .758 \\
PPh pasal 21 & 433.509 \\
PPh pasal 23 & 0 \\
PPh pasal 25 & 5.142 .298 .464 \\
PPh pasal 29 & 32.107 .490 \\
Pajak Penghasilan pasal 4(2) & 1.969 .764 .540 \\
PPN & 7.359 .888 .761 \\
Jumlah Pajak Yang Masih Harus Dibayar & \\
\hline
\end{tabular}

Langkah selanjutnya yaitu menghitung pajak tangguhan dengan mempertimbangkan beda sementara dari laba komersil dengan laba fiskal. Sesuai dengan Pernyataan Standar Akuntansi Keuangan No 46 mengenai pajak tangguhan, beban pajak tangguhan didapatkan dengan mengalikan persentasi pajak dengan beda waktu. Oleh karena itu, beban pajak tangguhan didapatkan: Aktiva (kewajiban) pajak tangguhan tahun $2010=$ beda sementara tahun $2010 \mathrm{x}$ persentasi tarif pajak badan.

Diketahui: beda sementara tahun $2009=2.287 .965 .331$

Persentasi tariff pajak $=25 \%$

Jadi, beban pajak tangguhan tahun $2009=2.287 .965 .331 \times 25 \%=571.991 .333$

BEDA WAKTU

Penyusutan aset sewa pembiayaan

Penyisihan Piutang 2.373.687.135

estimasi manfaat karyawan

$-$

Jumlah beda waktu

2.287.965.331

persentasi pajak

$25 \%$

BEBAN PAJAK TANGGUHAN $\quad 571.991 .333$

Saldo awal Aktiva (kewajiban) pajak 32.759 .520

tangguhan

JUMLAH KEWAJIBAN PAJAK

TANGGUHAN 
Berdasarkan perhitungan pajak tangguhan yang dilakukan sesuai dengan prosedur penerapan PSAK No. 46, maka laporan keuangan PT Bumi Sarana Utama harus disesuaikan. Pada laporan keuangan PT Bumi Sarana Utama, diketahui bahwa penyisihan piutang diakui sebagai beda tetap, oleh karena itu aktiva pajak tangguhan yang diakui hanya sebesar Rp. 21.430.451. maka jurnal penyesuaian yang harus dilakukan adalah:

\section{Jurnal Penyesuaian}

Aktiva pajak Tangguhan

Beban Pajak Tangguhan

Rp 550.560.881,75

Rp 550.560.881,75

\section{Kesimpulan dan Saran \\ Kesimpulan}

PT Bumi Sarana Utama merupakan salah satu perusahaan yang telah menerapkan PSAK No. 46 dalam menyusun laporan keuangannya. Hal ini dibuktikan dengan adanya pengakuan aktiva dan kewajiban pajak tangguhan pada laporan neraca perusahaan. Prosedur penerapan PSAK No. 46 yang dimiliki oleh perusahaan telah memperhitungkan konsekuensi pajak terhadap pelaporan keuangan.

PT Bumi Sarana Utama pada tahun 2009 telah mengakui adanya aktiva pajak tangguhan akibat perbedaan temporer antara perhitungan perusahaan dengan peraturan perpajakan. Berdasarkan prosedur yang dimiliki perusahaan, maka didapatkan Rp. 185.678.002 beban pajak tangguhan. Akibat adanya saldo awal aktiva pajak tangguhan sebesar Rp. 152.918.482 maka saldo kewajiban pajak tangguhan per 31 Desember 2009 adalah Rp. 32.759.520.

Pada tahun 2010, perusahaan kembali menerapkan prosedur pengakuan PSAK No. 46, namun berdasarkan perhitungan yang dilakukan, maka terdapat kesalahan besaran pengakuan aktiva pajak tangguhan yang dilakukan oleh perusahaan. Kesalahan ini terjadi akibat pengakuan penyisihan piutang perusahaan sebagai perbedaaan tetap oleh perusahaan yang mana seharusnya diakui sebagai perbedaan temporer.

Penyisihan piutang harus diakui sebagai perbedaan temporer karena di masa yang akan datang jika piutang tersebut benar-benar tidak dapat tertagih, maka beban ini dapat diakui oleh pajak. Perusahaan mengakui besar pajak tangguhan sebesar Rp. 21.430.451, sedangkan perhitungan berdasarkan prosedur penerapan PSAK No. 46 didapatkan nilai pajak tangguhan sebesar Rp. 571.991.333. oleh karena itu perlu dilakukan jurnal penyesuaian sebesar selisih pengakuan pajak tangguhan yaitu sebesar Rp 550.560.881,75

\section{Saran}

Berdasarkan hasil analisis, perusahaan disarankan untuk:

1. Melakukan jurnal penyesuaian dalam rangka mengikuti prosedur pengakuan PSAK No. 46;

2. Untuk selanjutnya, perusahaan harus benar-benar memperhatikan setiap perbedaan pengakuan antara pihak fiskus berdasarkan peraturan perpajakan 
dengan pihak perusahaan berdasarkan Pernyataan Standar Akuntansi Keuangan.

\section{DAFTAR PUSTAKA}

Agoes, Sukrisno. 2008. Akuntansi Perpajakan. Jakarta: Salemba Empat. Bohari. 2002. Pengantar Hukum Pajak. Jakarta: Raja Grafindo Persada.

Darsono dan Ashari. 2005. Pedoman Praktis Memahami Laporan Keuangan. Yogyakarta: Penerbit Andi.

Diana, Anastasia. 2009. Perpajakan Indonesia. Yogyakarta: Penerbit Andi

Direktorat Jenderal Pajak, Undang-Undang Republik Indonesia Nomor 17 Tahun 2000 Tentang Pajak Penghasilan Sebagaimana Telah Diubah Terakhir Dengan Undang-Undang Republik Indonesia Nomor 36 Tahun 2008.

Gunadi. 1997. Akuntansi Pajak. Jakarta: Grasindo. , 2002. Ketentuan Perhitungan dan Pelunasan Pajak Penghasilan. Jakarta: Salemba Empat. . 2009. Akuntansi Pajak. Jakarta: Grasindo.

Hanafi, Mamduh M dan Abdul Halim. 2002. Analisis Laporan Keuangan. Jakarta: Salemba Empat.

Harahap, Sofyan S. 2006. Analisa Kritis Atas Laporan Keuangan. Jakarta: Grasindo

Ikatan Akuntan Indonesia. 2011. Standar Akuntansi Keuangan. Jakarta: Salemba Empat.

Mardiasmo. 2008. Perpajakan. Edisi revisi. Yogyakarta: Penerbit Andi.

Pardiat. 2007. Akuntansi Pajak. Jakarta: Mitra Wacana Media.

Rahayu, Siti Kurnia. 2009. Perpajakan Indonesia. Yogyakarta: Graha Ilmu.

Suandy, Erly. 2003. Perencanaan pajak. Jakarta: Salemba Empat.

Waluyo. 2006. Perpajakan Indonesia. Jakarta: Salemba Empat. , 2008. Akuntansi Pajak. Jakarta: Salemba Empat.

Widyaningsih, Arisanti. 2011. Hukum Pajak dan Perpajakan. Jakarta: Salemba Empat. 